\title{
Coral as Environmental BioIndicators: Ecological and Morphological Effects of Gasoline on Gorgonian Corals, Leptogorgia virgulata
}

\author{
Michelle L. White \& Kevin B. Strychar (Corresponding author) \\ Department of Life Sciences, Texas A\&M University-Corpus Christi, Corpus Christi, Texas, 78412, USA \\ Tel: 361-825-5883Ｅ-mail: kevin.strychar@tamucc.edu
}

\begin{abstract}
Oil spills are the most common sources of pollution in marine ecosystems occurring worldwide, causing problems not only for benthic and pelagic organisms but also for terrestrial species that feed on marine organisms. Coral, more so than many other organisms, are sensitive to tiny changes in the marine environment, which makes them an excellent bioindicator of changing environmental conditions. In this study, Leptogorgia virgulata located in the Aransas Pass ship channel, Port Aransas, Texas was examined to determine the level of gasoline $(10 \mathrm{ppm}, 50 \mathrm{ppm}$, and $100 \mathrm{ppm})$ this species could tolerate. Our experimental research compared both coral-tips (the youngest and most rapid growing part of gorgonian corals) to the coral-bases (the older part of these coral) of $L$. virgulata. Affects were characterized by determining the number of sclerites sloughed off over seven days $(168 \mathrm{~h})$. Comparative analysis between treatments show that gasoline has a significant negative consequence, damaging coral tissue over time (ANOVA, $p=0.008 ; \alpha=0.05$ ). Similarly, the sensitivity of tips to bases was significantly different (ANOVA, $p=0.003 ; \alpha=0.05$ ). The coral-bases sloughed more cells and sclerites than the coral-tips indicating greater sensitivity to the gasoline treatments. This study also showed that at low concentrations, environmental managers may have as much as $48 \mathrm{~h}$ to mitigate the effects of a petroleum spill. Any clean-up not completed beyond that period of time will cause massive death to the coral L. virgulata and associated inhabitants, including potentially important sport fishes known to associate with these benthic fauna.
\end{abstract}

Keywords: BioIndicator species, Coral, Environmental impact, Gasoline, Leptogorgia sp., Oil spills, Pollution

\section{Introduction}

Oil spills are the most common sources of pollution in marine ecosystems occurring worldwide (Vieites et al., 2004). Even though ships contact underwater rocks or reefs and accidental collision events are rare, when spills do occur the effects are detrimental to most organisms, both in the marine and freshwater habitats and for the inland species that feed on the aquatic organisms (Loya and Rinkevich, 1979; Zhang et al., 2004). Examples of such events resulting in mass mortalities of organisms include the Torrey Canyon, Tsesis, Amoco Cadiz, Braer, and the Exxon Valdez oil spills. The effects of petroleum on many types of flora and fauna have been studied, including plants (Proffitt et al., 1995) and microorganisms (Piehler et al., 2003), corals (Moore and Swain, 1991), fish (Gregg et al., 1997), and birds (Macko and King, 1980). Proffit et al. (1995) demonstrated that mangroves exposed to acute (one-time) and chronic (weekly) oiling caused reduced growth rates and seedling survivorship. Gregg et al. (1997) tested the effects of diesel-contaminated sediment on the feeding behavior of goby fish. Results from assays indicated that fish feeding rates decreased with the increase of suspended diesel concentrations leading to mortality (Gregg et al., 1997). The National Research Council reports an estimated input of petroleum hydrocarbons to marine environments and estuaries each year to be approximately 1.7 to 8.8 million tons (Head and Swannell, 1999; Mills et al., 2003).

Crude oil is a natural product found within the earth's crust from which other types of petroleum products are synthesized. Boiling the oil through a process called distillation produces four types of products: refinery gas, liquefied petroleum gas, gasoline, and distillate fuels, such as diesel (EPA, 1999). Non-boiling oil is considered residual oil with high sulfur content comparable to tar, while the concentrate is comprised of low sulfur material. These low sulfur substances include kerosene, gasoline, diesel fuel, oil for heaters and boilers, and oil for oceanic ship engines (EPA, 1999). Although oil dispersants are commonly used for oil spills (i.e. Exxon Valdez) to break apart the oil mass, the dispersants can result in more harm to organisms, such as corals, than the crude oil (Lane and Harrison, 2000).

In the southern Gulf of Mexico (GOM), the Ixtoc 1 oil well slowly leaked thousands of barrels of petroleum oil over several months in 1979, affecting the gulf coasts of Mexico as well as the barrier islands of Texas (Hall et 
al., 1983). There was a 70\% reduction in infaunal organisms on the Padre and Mustang Island barrier islands as well as a buildup of hydrocarbons in the sediments along the shorelines (Chapman, 1984). Due to the large size of the barrier islands and low numbers of inlets and passes, damage to marine organisms in bays and estuaries were reduced or prevented. More recently in the northern GOM, an oil company called BP had an oil well pipeline ruptured following an explosion of an oil platform on April 20, 2010 (Mouawad, 2010). It is estimated that BP's rupture is releasing an estimated 5,000 to 95,000 barrels of crude oil per day; one barrel is 42 gallons, hence, the volume of oil being released is 210,000 to 4,000,000 gallons (approximately 790,000 to $15,100,000$ liters) per day (Schoof 2010) which is equivalent to the size of the Exxon Valdez spilling into the GOM every four days. It is still uncertain regarding how this oil spill, or the dispersants used to clean-up the oil, will have on the marine and freshwater environments in the northern GOM.

Although many studies have characterized the effects of oil on marine systems, very little data exists examining the effects of gasoline on near-shore reefs, however, some larger reefs such as the Great Barrier Reef (Australia), the Eilat reef (Red Sea), and the Florida Keys (USA) have been studied. Peters et al. (1981) and Moore and Swain (1991) suggest most petroleum chemicals cause harm to corals (i.e. loss of zooxanthellae or coral tissue degradation) within a short period of time. Reimer (1975) proposed that slow growth and slow tissue degradation can impair settling ability and competition for space. Loya and Rinkevich $(1979,1980)$ suggest that the damage is acute and not chronic causing reduced coral community growth via premature planulae release, inhibition of settlement, or delayed development of larvae. Oil type, dosage, environmental factors (i.e. wave turbulence, wind, or precipitation), biota, and previous exposure to contaminants are all factors that can lead to acute damage (Loya and Rinkevich, 1980). Bak (1987) observed a Caribbean coral reef surrounding a refinery in Aruba. Spatial distributions of stony corals were reduced down-current of the refinery as well as coral mortality as far as $15 \mathrm{~km}$ from the refinery station (Bak, 1987). Similarly, a study by Villanueva et al. (2008) documented the adverse effects of oil and gasoline on the survivorship, recruitment, and growth of coral larvae, Family Pocilloporidae. Te (1991) also discovered that concentrations of a $100 \mathrm{ppm}$ gasoline mixture caused complete mortality of hard coral planulae (Pocillopora damicornis).

Along the Texas coast, many near-shore habitats are populated with scleractinian corals, e.g. Oculina spp., and gorgonian corals, e.g. Leptogorgia spp. Generally, Leptogorgia are found along the east coast of North America from Chesapeake Bay to the reefs of Brazil in South America (Bayer, 1961). Body composition is determined by a variety of factors that include salinity and temperature (Bayer, 1961), water flow (Jeyasuria and Lewis, 1987), spatial distribution (Kinzie, 1970), and orientation in the water column (Wainwright and Dillon, 1969). Bayer (1961) observed that L. virgulata inhabits water with salinity concentrations ranging from 17 to 35 . Leptogorgia sp. displays a range of colors including yellow, orange, red, and even purple (Adams, 1980). The polyps are generally white and translucent, azooxanthellate (i.e. lacking the dinoflagellate symbiont Symbiodinium spp.), and are found along two sides of long and tapered coral branches (Bayer, 1961; Patton, 1972).

Patton (1972) suggests that L. virgulata provides important habitat and food for a variety of organisms. Macroscopic and microscopic invertebrates are the most abundantly associated organisms and include snails, shrimp, nudibranchs, bivalves, and barnacles. Dailey (2009) recently observed several important sport and aquarium fish associated with Leptogorgia sp., indicating that these coral may play an important role as fishery habitat. As a result, we question whether these coral are capable of surviving a disaster, such as a large gasoline spill or increased boating activity resulting from tourism, in the jetty ecosystems which they are most commonly found. We also question how long these coral could survive and at what concentrations. Such information is vital to environmental managers whose responsibilities are to protect our natural resources.

\section{Materials and Methods}

The Aransas Pass ship channel ( $27^{\circ} 50^{\prime} 15^{\prime \prime} \mathrm{N}, 97^{\circ} 02^{\prime} 40^{\prime \prime} \mathrm{W}$, Figure 1) is a major waterway connecting the Gulf of Mexico (GOM) with the Aransas and Corpus Christi Bays in Texas. Large and small ships use the channel to travel into and out of the Port of Corpus Christi; small boats use the channel for recreational purposes such as fishing. This creates a potential problem for possible spill hazards in GOM waters due to an increased amount of cargo and vessel trafficking. In 2008, approximately 6,000 cargo, tanker, and barge vessels entered into the Corpus Christi port carrying approximately 71,368,984 tons of petroleum products (Port of CC, 2009). With so many vessels entering and exiting the ship channel it is proposed that in the event of an oil spill, the gorgonian corals (Leptogorgia virgulata) as well as fish and invertebrates will encounter reduction in population sizes or even mass mortality. 


\subsection{Study Site and Collection of Gorgonian coral, Leptogorgia virgulata, samples}

Leptogorgia sp. was collected from the Port Aransas jetties by removing the organism from the water by hand and placing them in an aerated 38 liter bucket. Approximately $50 \mu \mathrm{L}$ of a phytoplankton mixture $\left(1 \times 10^{6}\right.$ cells $\mathrm{mL}^{-1}$; DT's live marine phytoplankton ${ }^{\circ}$, Illinois, USA) was added to help ensure coral survivorship and reduce any stress during transport. At the time of collection, ambient water temperatures were $23^{\circ} \mathrm{C}$ and practical salinities 32 . We are using practical salinity which is a dimensionless unit, as recommended by the International Association for the Physical Sciences of the Oceans (IAPSO; Council of Science Editors, 2006) and adopted by the International System of Units (SI) in 1985. Samples were then transported to the laboratory at Texas A\&M University - Corpus Christi (TAMUCC), approximately 30 to 40 minutes (min) from the collection site, and placed into a 115 liter tank with sufficient water flow and aeration. Water was changed by removing a portion of the total water volume every three days for two weeks to acclimate the coral from jetty water to artificial seawater. For example, after the first three days, $25 \%$ of the jetty water was removed and replaced with artificial seawater. The following three days, the 115 liter tank was filled with a 50:50\% concentration consisting of jetty water : artificial seawater mixture. After nine days, the holding tank contained $75 \%$ artificial seawater, $25 \%$ jetty water, and on days $12-15$, the coral were acclimated to $100 \%$ artificial seawater. After each water change, the coral were fed $5 \mathrm{~mL}$ of a phytoplankton mixture $\left(3 \times 10^{6}{\text { cells } \mathrm{mL}^{-1} \text {; DT's Live Marine Phytoplankton }}^{\circ}\right.$, Illinois, USA) to help ensure polyp survivorship. Observations of polyps protruding in addition to the absence of external tissue loss (i.e. tissue sloughing) was used to help assess whether the coral were healthy and stress-free (Kim et al., 2000).

\subsection{Experimental set-up}

In order to examine the effects of gasoline on coral, preliminary studies were conducted to determine how to ensure gasoline would stay in suspension over the duration of our experimental study, since gasoline is hydrophobic. We determined that sodium dodecyl sulfate (SDS) was less harmful to coral than other surfactants (e.g. hand soap) and consistently ensured uniform mixing of gasoline in seawater. In addition, SDS showed no petroleum residue accumulating on the surface of the water. Preliminary studies also showed that though concentrations of SDS as high as $2.35 \mathrm{mg}$ would not adversely affect Leptogorgia sp. (Table 1), $1 \mathrm{mg}$ was sufficient to mix gasoline in seawater.

\subsection{Methodology of comparing gasoline treatments on coral-tips from Leptogorgia virgulata}

Twenty fragments of Leptogorgia virgulata were collected from the Aransas Pass ship channel jetties at various locations and depths. The coral, $7.7 \mathrm{~cm}$ in length, were excised from five parent colonies; four coral tip fragments per colony (Figure 2).

Tips of $L$. virgulata fragments were used in all experiments for two reasons. First, we were able to collect tips without removing entire coral colonies, and thus had minimal impact on the environment. Second, we wanted to examine the response of multiple individuals and using tips from various colonies removed any variability that may be associated with differences within a particular coral and its ability to tolerate pollution. In a second study, we then compared sensitivity of different parts of the coral (e.g. bases of a coral vs. tips) to help determine the variability within individuals to gasoline stress.

Gasoline was obtained from a local gas station and was placed into a closed, well-labeled container and transported to the TAMUCC laboratory. Twenty one-liter glass incubation containers (GICs) were labeled with the corresponding treatment concentrations $(0,10,50$, and $100 \mathrm{ppm})$ and placed randomly in five rows of four GICs (Figure 3). A randomized block design was used to avoid issues of statistical independence. Five one-liter GICs were also assigned as SDS controls; all GICs contained $1 \mathrm{mg}$ of SDS. Aerators were used with Pasteur pipettes to ensure oxygen was replenished within the water column in addition to the mixing of gasoline. Before placing any coral fragments into the GICs, the weight of each coral fragment was calculated to help determine if the coral weight was correlated with the number of sclerites lost and tissue sloughing. Sloughing is described as external epithelial coral tissue (ectoderm) falling off the central axis of the organism (Harrington et al., 2004). It is hypothesized that the higher the concentration of sclerites sloughed off, the more visible the degradation of coral and the more stress the species' experience. Coral fragments excised from the parent colonies were then attached to a petri dish with non-toxic marine epoxy (Marineland ${ }^{\circ}$ ), and one fragment was placed in each of the twenty one-liter GICs. For any given concentration, each replicate contained a separate tip from each of the five parent coral colonies (Figure 3).

Every $12 \mathrm{~h}$ for $168 \mathrm{~h}$ (i.e. 7 days), $1 \mathrm{~mL}$ of water was extracted from each of the twenty treatment GICs with a plastic pipette. Each $1 \mathrm{~mL}$ aliquot sample was placed in a separate labeled test tube. Every other day $(48 \mathrm{~h})$, the coral were fed a $0.006 \%$ phytoplankton mix $(\sim 50 \mu \mathrm{L}$; DT's live marine phytoplankton) to ensure coral health; 
extruding polyps were a sign of healthy coral (Bayer, 1961). Polyp extrusion was not a focal point for the experimental assays, however, throughout the experiment more than $50 \%$ of polyps were extruding among each treatment. Aliquot samples were then observed using a compound microscope and a Sedgwick-Rafter slide (Capizzi and Schwartzbrod, 2001) to enumerate the number of sclerites sloughed off by the coral (Harrington et al., 2004). Once all 160 aliquot samples (20 aliquots per $12 \mathrm{~h}$ interval, during seven days) were viewed with the Sedgwick-Rafter and the data recorded, data analysis was done using SPSS (Statistical Package for the Social Sciences, V17.0).

\subsection{Methodology of comparing coral-tips versus coral-bases from Leptogorgia virgulata}

To compare coral-tips to coral-base fragments, colonies of $L$. virgulata used in these analyses were collected at the same depth and location as the coral-tips and followed the same acclimation design as previously described. The coral-base fragment experiment was initiated at the same time as the coral-tip experiment. Hence, every $12 \mathrm{~h}$ for seven days, $1 \mathrm{~mL}$ of water was collected from each of the GICs and placed in labeled test tubes before any sloughed tissue was enumerated.

It is hypothesized that the L. virgulata coral-base fragments will exhibit a higher tolerance to gasoline treatments than the coral-tip fragments. Our speculation is based on the fact that the base of a L. virgulata coral colony is much older, but slower growing than the fast growing tips. Hence, it is plausible that the older growth forms have likely been exposed to more pollution related stress than the younger newly formed coral-tips.

Upon completion of the experiment, any surviving coral-tip and coral-base fragments were returned to the Aransas Pass jetties and all experimental treatment water was disposed of according to the Health and Safety standards of TAMUCC. The GICs were washed in de-ionized (DI) water, methanol, followed by a $10 \%$ nitric acid bath for $4 \mathrm{~h}$, and rinsed in Milli-Q water.

\subsection{Statistical Analyses}

A paired t-test was used for preliminary studies to compare the effects of SDS on Leptogorgia sp. fragments. A one-way ANOVA was used to determine any significance between treatment and control concentrations for the L. virgulata tip experiment. An LSD post hoc test was also used to verify any significant difference among the gasoline and control concentrations (Day and Quinn, 1989). An ANOVA was also used to determine if time was a significant variable affecting survival of coral tips per chance a gasoline spill were to occur within the Aransas Pass ship channel. A paired samples test was used to evaluate significance between treatment and control concentrations of $L$. virgulata base fragments. To compare tip $v s$. base fragments, a paired t-test was utilized to determine if coral location was significant when exposed to such treatments.

\section{Results}

\subsection{Preliminary study: Effects of sodium dodecyl sulfate (SDS) on coral}

Over the duration of the preliminary study, no visual injuries were evident on any of the coral, nor could any sloughing be observed on the coral fragments. The polyps were protruding from the coral tissue and were extended $75 \%$ of the time over the duration of the seven day experimental period. A paired t-test $(\mathrm{p}=0.324$; Table 1) indicated no significant difference between the control treatments and the treatment GICs containing SDS.

\subsection{Effects of gasoline treatments on coral-tips excised from Leptogorgia virgulata}

In the treatments tested, all of the coral fragments maintained their tissue (i.e. no major sloughing was observed) and polyps were protruding for at least $120 \mathrm{~h}$, after which a substantial loss of tissue occurred (Figure 4). The 50 ppm treatment showed coral having the greatest loss of sclerites at $120 \mathrm{~h}$, followed by treatments at $10 \mathrm{ppm}$ and $100 \mathrm{ppm}$ (Figure 4). Statistical analysis of the coral-tip fragments indicate that the losses of sloughed tissue between treatments were significant (ANOVA, $p=0.008, \alpha=0.05$; Table 2).

\subsection{Effects of gasoline treatments on coral-tips versus coral-bases from Leptogorgia virgulata}

Comparative analysis between the coral-base fragments and the coral-tip fragments show a significant difference between each of these locations on a coral colony (t-test, $p=0.003, \alpha=0.05$; Table 3 ). The tips had a large number of sclerites sloughed between 108 and $132 \mathrm{~h}$ vs. the coral-bases, which had multiple sclerites sloughed off between 60 to $156 \mathrm{~h}$ (Figure 5).

\section{Discussion}

Oil spills threaten the aquatic environment world-wide. Not only is water quality affected but birds, mammals, and invertebrates, including corals, are affected too (Chapman, 1984; Piatt et al., 1990; Moore and Swain, 1991). Leptogorgia virgulata, however, is one type of coral species in which very little data exists describing the effects 
petroleum products may have on its survivorship. Because L. virgulata does not have a fortified calcium carbonate structure as commonly observed in scleractinian corals, this organism must rely on sclerites for support and/or protection (O’Neal and Pawlik, 2002; Chang et al., 2007) against external disturbances such as wave activity, predator grazing, and even exposure to damaging chemicals. Statistical analysis showed there were significant differences with coral health and coral fragment location. Data indicate that coral were not affected, or at least showed few if any symptoms in the first $48 \mathrm{~h}$. As a result, environmental managers may have as many as two days to respond and begin clean-up during gasoline spills. Studies have shown that once a gasoline spill is detected, the time it takes to clean-up a spill of nominal size can be done within $48 \mathrm{~h}$, however, full recovery of all spilt petroleum products may take weeks to months, if not years (US Congress, 1991; NOAA, 1992; Hoff, 1995).

Comparison of coral tips $v s$. bases of a gorgonian coral colony was analyzed as we hypothesized that the older polyps found at the base would better at tolerating environmental hazards. However, our data showed that the coral-tips were better at tolerating high concentrations of gasoline. It is possible that the reason the coral-bases are more susceptible is that any excess energy metabolized by the coral is used by the coral tips, and therefore, less energy is available for the coral-bases to mount a defense (Puglisi et al., 2002). Puglisi et al. (2002) describes a similar event in relation to predation and soft coral's structural and chemical defenses. These authors found that the tips of a coral needed to be better defended against predation and as a result, coral-tips had more sclerites and chemical defenses than coral-bases. In our study, data analysis often resulted in more sclerites enumerated from coral-bases than coral-tips. Van Alstyne and Paul (1992) suggested that this is largely due to the age of the corals bases, resulting in more sclerites accumulating over time. Never the less, it is important to realize that any significant loss of the sclerites resulting from long term exposure to petroleum products will result in the death of the coral colony. As a result of mass coral mortality, the habitat will also lose associated shrimp, snails, and bivalves (Patton, 1972) as well as sport and aquarium-traded fish that are known to co-exist with L. virgulata (Harris et al., 2006).

This study also found that time plays a significant factor in the survival of coral during a gasoline spill. In all treatments, coral did not slough any tissue within the first $48 \mathrm{~h}$ indicating that environmental managers potentially have that period of time to ameliorate any spills.

\section{Conclusion}

Leptogorgia virgulata is located along the eastern coastline of the United States in the Atlantic Ocean as well as in the Gulf of Mexico and along the Mexican coastline (Bayer, 1961). Future studies that need attention include the analysis of soft corals from high ship trafficking areas, as observed here, compared to areas with low or minimal ship traffic. Other studies that need to be conducted, now with the major oil spill currently occurring in the Gulf of Mexico, include how the break-down products of oil affect near-shore corals. Similarly, studies should be conducted to determine how oil dispersants affect corals. It is currently estimated that the amount of oil dispersant used to clean up the BP oil spill in the Gulf of Mexico is far greater than the oil spill itself.

It is also recommended that studies examining the chronic (months) vs. acute (weeks) effects of a gasoline/oil spill. It is well known that some species exposed to environmental pollutants over a long period of time adapt to such contaminants (Hackney et al., 1976; López-Rodas et al., 2006). Finally, invertebrates that commonly associate with near-shore coral should be tested such as snails, shrimp, and bivalves (Patton, 1972) as these species play an integral role as prey for predatory fish.

\section{Acknowledgements}

We are grateful to the Texas Research Development Fund for grants to KBS and Texas Parks and Wildlife (TPW) for licenses to KBS to collect near-shore corals.

\section{References}

Adams, R.O. (1980). Investigations of color, morphology and development of the sea whip, Leptogorgia virgulata (Lamarck) (Cnidaria: Octocorallia: Gorgonacea). Ph.D. Dissertation, Florida State University, Tallahassee.

Bak, R. P. M. (1987). Effects of chronic oil pollution on a Caribbean coral reef. Marine Pollution Bulletin, 18, 534-539.

Bayer, F.M. (1961). The shallow-water Octocorallia of the West Indian region. Martinus Nijhoff, The Hague, Netherlands. 373 p. 
Capizzi, S., \& Schwartzbrod, J. (2001). Surface properties of Ascaris suum eggs: hydrophobic potential and Lewis acid-base interactions. Colloid Surface B, 22, 99-105.

Chang, W.L., Chi, K.J., Fan, T.Y., \& Dai, C.F. (2007). Skeletal modification in response to flow during growth in colonies of the sea whip, Junceella fragilis. Journal of Experimental Marine Biology and Ecology, 347, 97-108.

Chapman, B.R. (1984). Seasonal abundance and habitat-use patterns of coastal bird populations on Padre and Mustang Island barrier beaches [Following the Ixtoc 1 oil spill]. U.S. Fish Wildl. Serv. FWS/OBS-83/31. 73pp.

Council of Science Editors. (2006). The CSE manual for authors, editors, and publishers. ( $7^{\text {th }}$ ed.). Reston, VA. $658 \mathrm{p}$.

Dailey, A. (2009). Leptogorgia spp. as fish habitat found along the Port Aransas, Texas South Jetty. M.S. Thesis. Texas A\&M University - Corpus Christ. 70 pp.

Day, R.W., \& Quinn, G.P. (1989). Comparison of treatments after an analysis of variance in ecology. Ecological Monographs, 59, 433-463.

Environmental Protection Agency. (1999). In-use marine diesel fuel. EPA Contract No. 68-C-98-170. Engine Programs and Compliance Division, Office of Mobile Sources. 21pp.

Gregg, J.C., Fleeger, J.W., \& Carman, K.R. (1997). Effects of suspended, diesel-contaminated sediment on feeding rate in the darter goby, Gobionellus boleosoma (Teleostei: Gobiidae). Marine Pollution Bulletin, 34, 269-275.

Hackney, J.D., Linn W.S., Buckley R.D., \& Hislop H.J. (1976). Studies in adaption to ambient oxidant air pollution: effects of ozone exposure in Los Angeles residents vs. new arrivals. Environmental Health Perspectives, 18, 141-146.

Hall, R.J., Belisle, A.A., \& Sileo, L. (1983). Residues of petroleum hydrocarbons in tissues of sea turtles exposed to the Ixtoc 1 oil spill. Journal of Wildlife Diseases, 19, 106-109.

Harrington, L., Fabricius, K., De’ Ath, G., \& Negri, A. (2004). Recognition and selection of settlement substrata determine post-settlement survival in corals. Ecology, 85, 3428-3427.

Harris, L.E., Dillon, K.L., \& Herren, L. (2006). Martin County's Nearshore Mitigation Reefs Year-6 monitoring Report. Martin County Engineering Department, Florida, USA.

Head, I.M., \& Swannell, R.P.J. (1999). Bioremediation of petroleum hydrocarbon contaminants in marine habitats. Current Opinion in Biotechnology, 10, 234-239.

Hoff, R.Z. (1995). Responding to oil spills in coastal marshes: The fine line between help and hinderance. Hazmat Report 96-1, NOAA. 17 p.

Jeyasuria, P., \& Lewis, J.C. (1987). Mechanical Properties of the axial skeletons in gorgonians. Coral Reefs, 5, 213-219.

Kinzie, R.A. III. (1970). The ecology of gorgonians (Cnidaria, Octocorallia) of Discovery Bay, Jamaica. Ph.D. Dissertation. Yale University, New Haven. 107 p.

Lane, A., \& Harrison, P.L. (2000). Effects of oil contaminants on survivorship of larvae of the scleractinian reef corals Acropora tenuis, Goniastrea aspera, Platygyra sinensis from the Great Barrier Reef. Proceedings of the $9^{\text {th }}$ International Coral Reef Symposium, Bali, Indonesia, 1, 403-408.

López-Rodas, V., Maneiro E., \& Costas E. (2006). Adaptation of cyanobacteriaand microalgae to extreme environmental changes derived from anthropogenic pollution. Limnetica, 25, 403-410.

Loya, Y., \& Rinkevich, B. (1979). Abortion effect in corals induced by oil pollution. Marine Ecology Progress Series, $1,77-80$.

Loya, Y., \& Rinkevich, B. (1980). Effects of oil pollution on coral reef communities. Marine Ecology Progress Series, 3, 167-180.

Macko, S.A., \& King, S.M. (1980). Weathered oil: effect on hatchability of heron and gull eggs. Bulletin of Environmental Contamination and Toxicology, 25, 316-320.

Mills, M.A., Bonner, J.S., McDonald, T.J., Page, C.A., \& Autenrieth, R.L. (2003). Intrinsic bioremediation of a petroleum-impacted wetland. Marine Pollution Bulletin, 46, 887-899.

Moore, E.A., \& Swain, H.M. (1991). Potential ecological impacts of an oil spill in the Florida Keys. National 
Marine Sanctuary Program. [Online] Available: http://ieeexplore.ieee.org/stamp/stamp.jsp?arnumber=00606516.

Mouawad J. (2010). For BP, a history of spills and safety lapses. [Online] Available: http://www.nytimes.com/2010/05/09/business/09bp.html.

NOAA. (1992). Oil spill case histories (1967 - 1991): Summaries of significant U.S. and international spills. Report no. HMRAD 92-11.224 p.

O'Neal, W., \& Pawlik, J.R. (2002). A reappraisal of the chemical and physical defenses of Caribbean gorgonian corals against predatory fishes. Marine Ecology Progress Series, 240, 117-126.

Patton, W.K. (1972). Studies on the animal symbionts of the gorgonian coral, Leptogorgia virgulata (Lamarck). Bulletin of Marine Science, 22, 419-431.

Peters, E.C., Meyers, P.C., Yevich, P.P., \& Blake, N.J. (1981). Bioaccumulation and histopathological effects of oil on a stony coral. Marine Pollution Bulletin, 12, 333-339.

Piatt, J.F., Lensink, C.J., Butler, W., Kendziorek, M., \& Nysewander, D.R. (1990). Immediate impact of the 'Exxon Valdez' oil spill on marine birds. The Auk: Quartely Journal of Ornithology, 107, 387-397.

Piehler, M.F., Winkelmann, V., Twomey, L.J., Hall, N.S., Currin, C.A., \& Paerl, H.W. (2003). Impacts of diesel fuel exposure on the microphytobenthic community of an intertidal sand flat. Journal of Experimental Marine Biology and Ecology, 297, 219-237.

Port of Corpus Christi. (2009). Port Statistics: yearly statistics. [Online] Available: http://www.portofcorpuschristi.com/general-information/statistics/yearly-statistics.html.

Proffitt, C.E., Devlin, D.J., \& Lindsey, M. (1995). Effects of oil on mangrove seedlings grown under different environmental conditions. Marine Pollution Bulletin, 30, 788-793.

Puglisi, M.P, Paul, V.J., Biggs, J., \& Slattery, M. (2002). Co-occurrence of chemical and structural defenses in the gorgonian corals of Guam. Marine Ecology Progress Series, 239, 105-114.

Reimer, A.A. (1975). Effects of crude oil on corals. Marine Pollution Bulletin, 6, 39-43.

Schoof R. (2010). Gulf oil spil leak now pegged at 95,000 barrels a day. McClatchy Newspapers, posted Wednesday, May $19 . \quad$ [Online] Available: http://www.mcclatchydc.com/2010/05/19/94467/engineer-oil-spill-videos-show.html.

Te, F.T. (1991). Effects of two petroleum products on Pocillopora damicornis planulae. Pacific Science, 45, 290-298.

U.S. Congress. (1991). Bioremediation for Marine Oil Spills - Background Paper, OTA-BP-O-70. Office of Technology Assessment, Washington, DC.

van Alstyne, K.L., \& Paul, V.J. (1992). Chemical and structural defenses in the sea fan Gorgonia ventalina: effects against generalist and specialist predators. Coral Reefs, 11:155-159.

Vieites, D.R., Nieto-Román, S., Palanca, A., Ferrer, X., \& Vences, M. (2004). European Atlantic: the hottest oil spill hotspot worldwide. Naturwissenschaften, 91, 535-538.

Villanueva, R.D., Montano, M.N.E., \& Yap, H.T. (2008). Effects of natural gas condensate-water accommodated fraction on coral larvae. Marine Pollution Bulletin, 56, 1422-1428.

Wainwright, S.A. and J.R. Dillon. (1969). On the Orientation of Sea Fans (Genus Gorgonia). Biological Bulletin, 136, 130-139.

Zhang, J.F., Wang, X.R, Guo, H.Y., Wu, J.C., \& Xue, Y.Q. (2004). Effects of water-soluble fractions of diesel oil on the antioxidant defenses of the goldfish, Carassius auratus. Ecotoxicology and Environmental Safety, 58, $110-116$. 
Table 1. Statistical analysis using paired samples t-test comparing the effects of sodium dodecyl sulfate (SDS) to control treatments. There is no significant difference between the control and SDS treatments $(p=0.324 ; \alpha=$ $0.05)$. Statistical parameters include $\alpha=0.05, \mathrm{t}=$ sample distribution, $\mathrm{df}=$ degrees of freedom

\begin{tabular}{|c|c|c|c|c|c|c|c|c|}
\hline & \multicolumn{9}{|c|}{ Paired Differences } & \multicolumn{2}{c|}{} \\
\hline & \multicolumn{9}{|c|}{} & $\begin{array}{c}95 \% \text { Confidence } \\
\text { Interval of the } \\
\text { Difference }\end{array}$ & \multicolumn{2}{|c|}{} \\
\hline $\begin{array}{c}\text { Control } \\
\text { versus } \\
\text { SDS }\end{array}$ & Mean & $\begin{array}{c}\text { Standard } \\
\text { Deviation }\end{array}$ & $\begin{array}{c}\text { Standard } \\
\text { Error of } \\
\text { the Mean }\end{array}$ & Lower & Upper & t & $\begin{array}{c}\text { Degrees } \\
\text { of } \\
\text { Freedom } \\
\text { (df) }\end{array}$ & $\begin{array}{c}\text { Significance } \\
\text { (2-tailed) }\end{array}$ \\
\cline { 2 - 9 } & 6.95 & 21.09 & 6.67 & -8.13 & 22.03 & 1.042 & 9 & 0.324 \\
\hline
\end{tabular}

Table 2. One-way ANOVA comparing the average number of sclerites sloughed (i.e. lost / expelled) between excised coral-tips of Leptogorgia virgulata and time. Statistical parameters include $\alpha=0.05$, df - degrees of freedom, and F - the factorial statistic

\begin{tabular}{|l|c|c|c|c|c|}
\hline & $\begin{array}{c}\text { Sum of } \\
\text { Squares }\end{array}$ & $\begin{array}{c}\text { Degrees of } \\
\text { Freedom (df) }\end{array}$ & $\begin{array}{l}\text { Mean } \\
\text { Square }\end{array}$ & F Statistic & $\begin{array}{c}\text { 95\% } \\
\text { Significance (p) }\end{array}$ \\
\hline $\begin{array}{l}\text { Between } \\
\text { groups }\end{array}$ & 51.237 & 13 & 3.941 & 2.696 & 0.008 \\
\hline Within groups & 61.40 & 42 & 1.462 & & \\
\hline Total & 112.637 & 55 & & & \\
\hline
\end{tabular}

Table 3. Statistical analysis using paired samples t-test comparing the effects of Leptogorgia virgulata coral-tips versus coral-bases at gasoline concentration $50 \mathrm{ppm}$. Statistical parameters include $\alpha=0.05, \mathrm{t}=$ sample distribution, $\mathrm{df}=$ degrees of freedom

\begin{tabular}{|c|c|c|c|c|c|c|c|c|}
\hline \multirow{4}{*}{\begin{tabular}{|c|}
$\begin{array}{c}\text { Coral-tips } \\
\text { (50 ppm) } \\
\text { versus }\end{array}$ \\
$\begin{array}{c}\text { Coral-bases } \\
(50 \mathrm{ppm})\end{array}$
\end{tabular}} & \multicolumn{5}{|c|}{ Paired Differences } & & & \\
\hline & \multicolumn{3}{|c|}{ 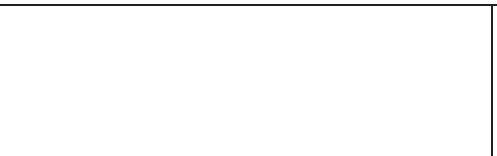 } & \multicolumn{2}{|c|}{$\begin{array}{l}95 \% \text { Confidence } \\
\text { Interval of the } \\
\text { Difference }\end{array}$} & \multirow[b]{2}{*}{$\mathrm{t}$} & \multirow[b]{2}{*}{$\begin{array}{l}\text { Degrees } \\
\text { of } \\
\text { Freedom } \\
\text { (df) }\end{array}$} & \multirow[b]{2}{*}{$\begin{array}{l}\text { Significance } \\
\text { (2-tailed) }\end{array}$} \\
\hline & Mean & $\begin{array}{l}\text { Standard } \\
\text { Deviation }\end{array}$ & $\begin{array}{l}\text { Standard } \\
\text { Error of } \\
\text { the Mean }\end{array}$ & Lower & Upper & & & \\
\hline & -4.39 & 4.45 & 1.19 & -6.957 & -1.814 & -3.684 & 13 & 0.003 \\
\hline
\end{tabular}




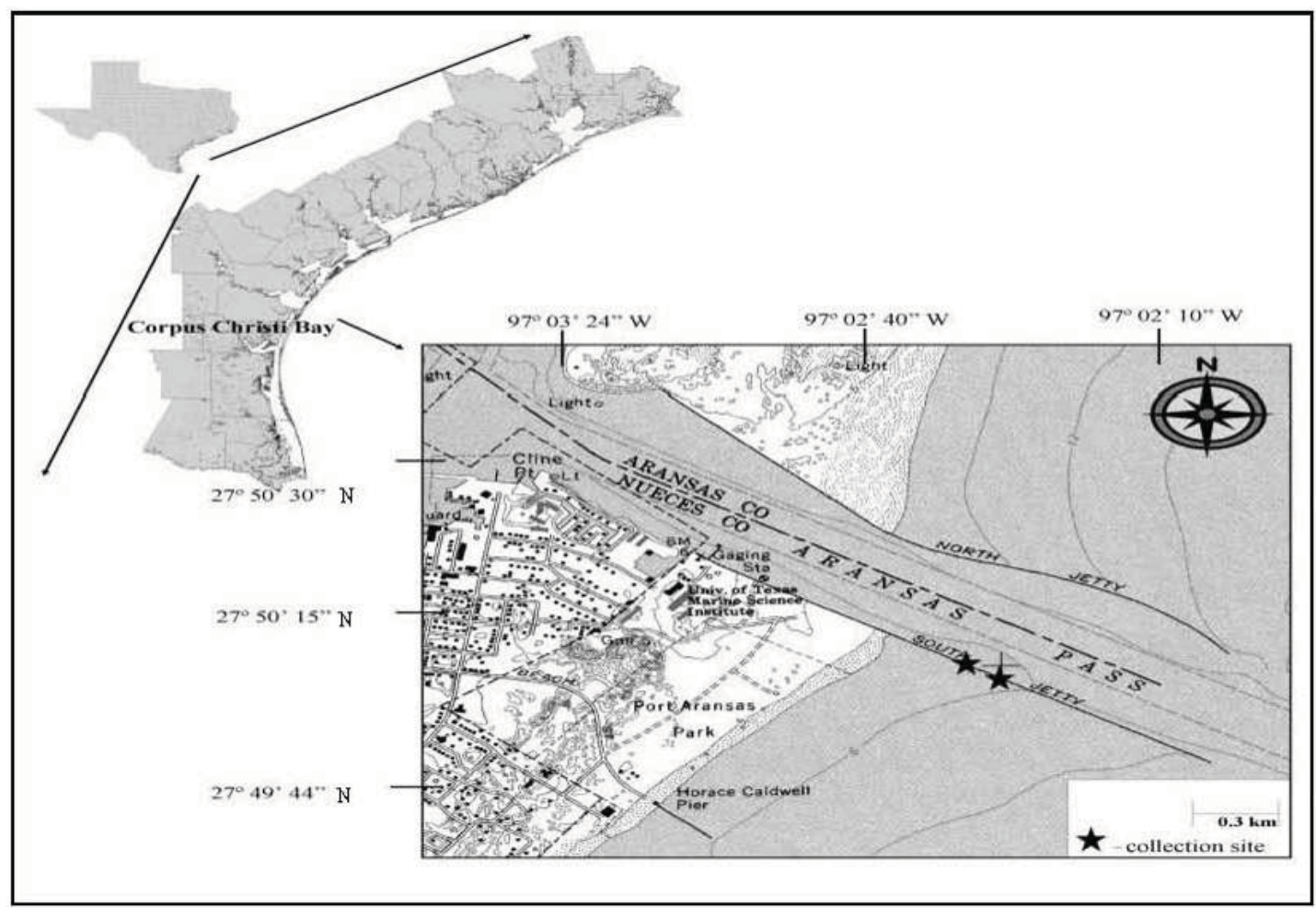

Figure 1. Location of sampling sites on the south jetty, Port Aransas, Nueces County, Texas, USA. Samples of the gorgonian coral, Leptogorgia virgulata, were collected randomly at the asterisks in the figure

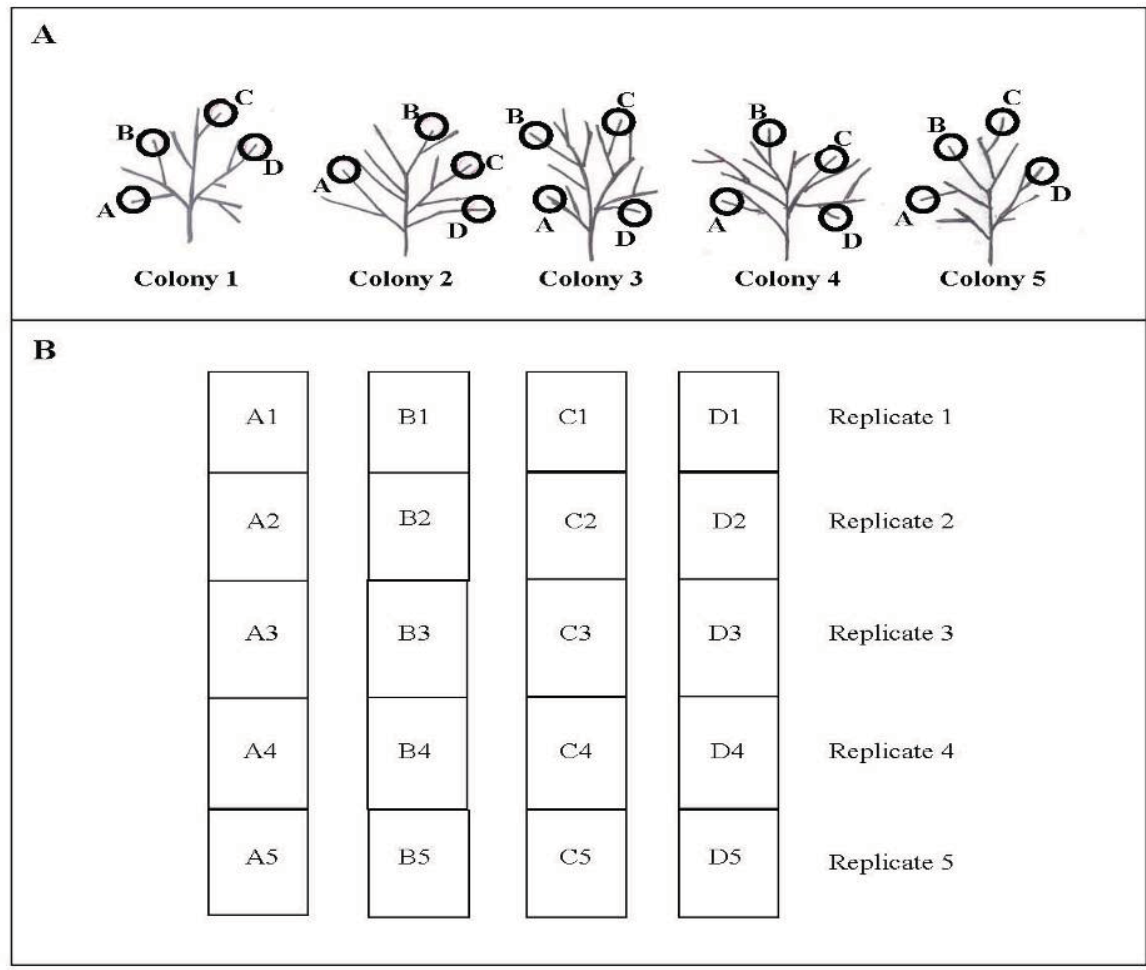

Figure 2. Panel A depicts the location of excised coral tips from each of the five Leptogorgia virgulata parent colonies and their placement (Panel B) as replicates used for experimental analysis of gasoline. Numbers 1 to 5 denote the parent colony a particular coral tip was excised from and letters A to D indicate replication 


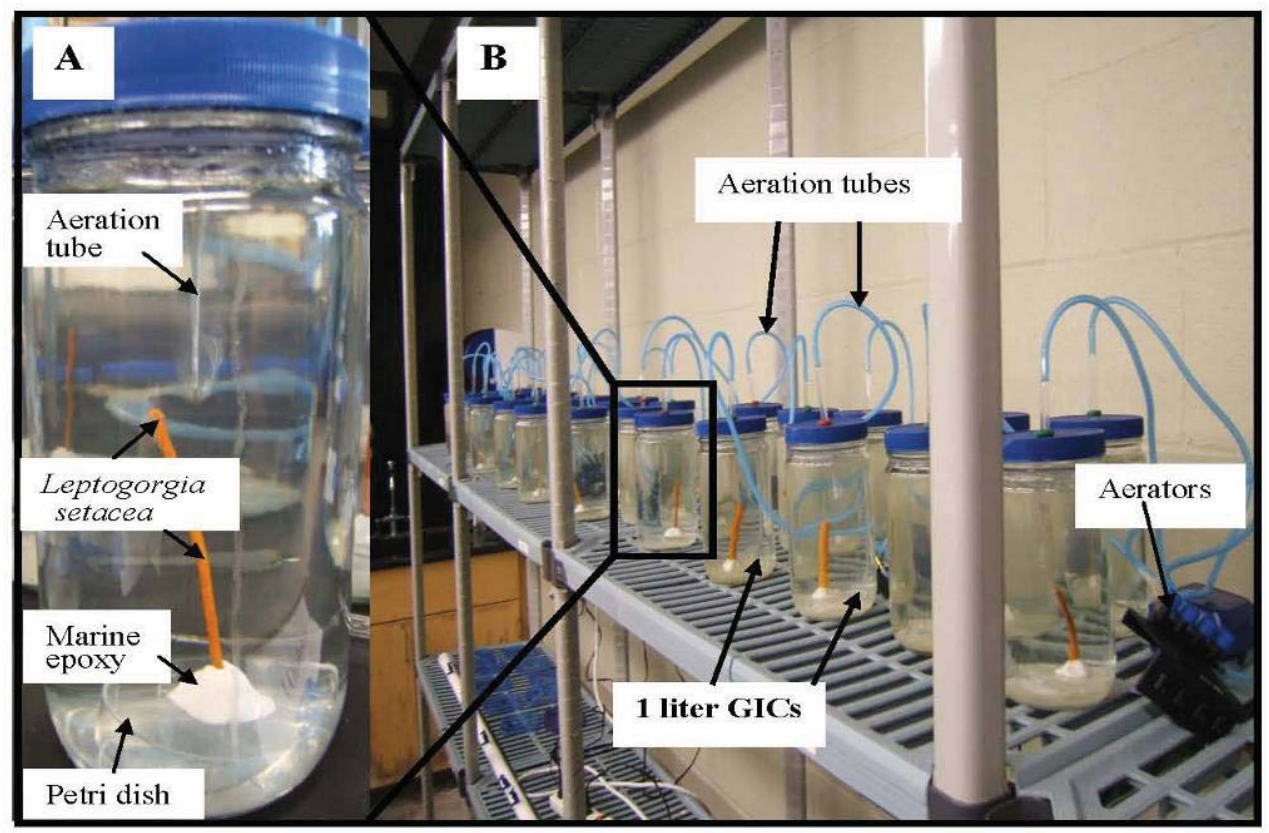

Figure 3. Panel A. One liter glass incubation containers (GICs) each contained a coral-tip fragment of Leptogorgia virgulata attached to a petri dish via non-toxic marine epoxy and placed at the bottom of the container; each GIC had an aeration tube. Panel B. A random block statistical design was used to analyze all replicates of all gasoline treatments at the same time; randomization helps to eliminate treatment error and human bias

\section{Coral-Tip Fragments}

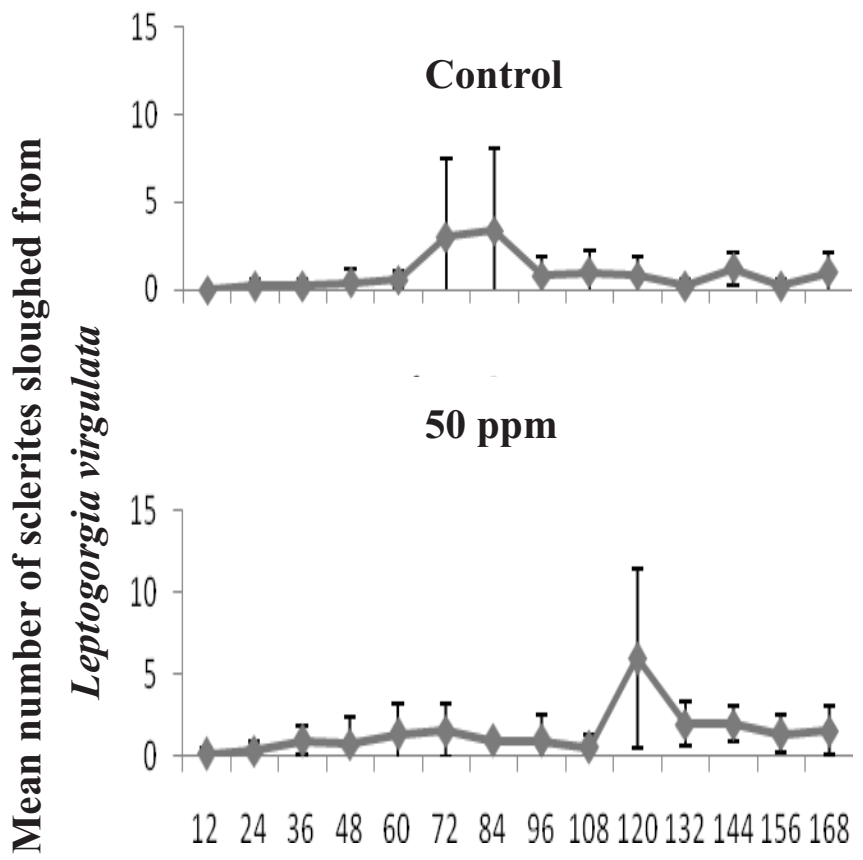

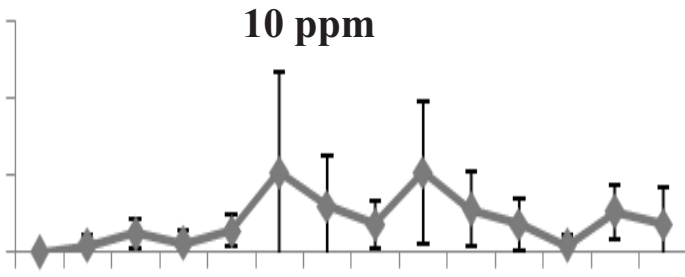

100 ppm

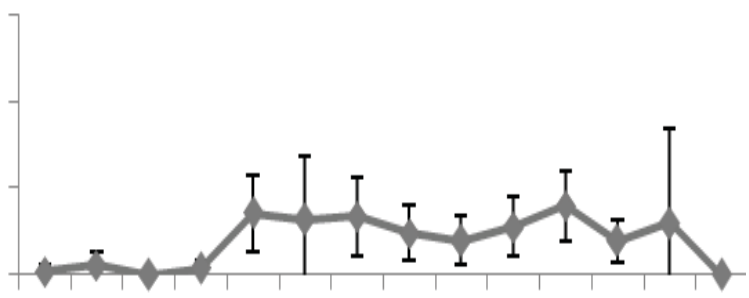

$122436486072 \quad 8496108120132144156168$

Time (h)

Figure 4. Average number of sclerites sloughed (i.e. lost/expelled) from the gorgonian coral Leptogorgia virgulata when exposed to various gasoline treatments (control $=0 \mathrm{ppm}, 10 \mathrm{ppm}, 50 \mathrm{ppm}, 100 \mathrm{ppm}$ ) over a time period of $168 \mathrm{~h}$ (7 days); sampling occurred every $12 \mathrm{~h}$. Error bars represent $95 \%$ confidence intervals 


\section{Coral-tips: 50 ppm}

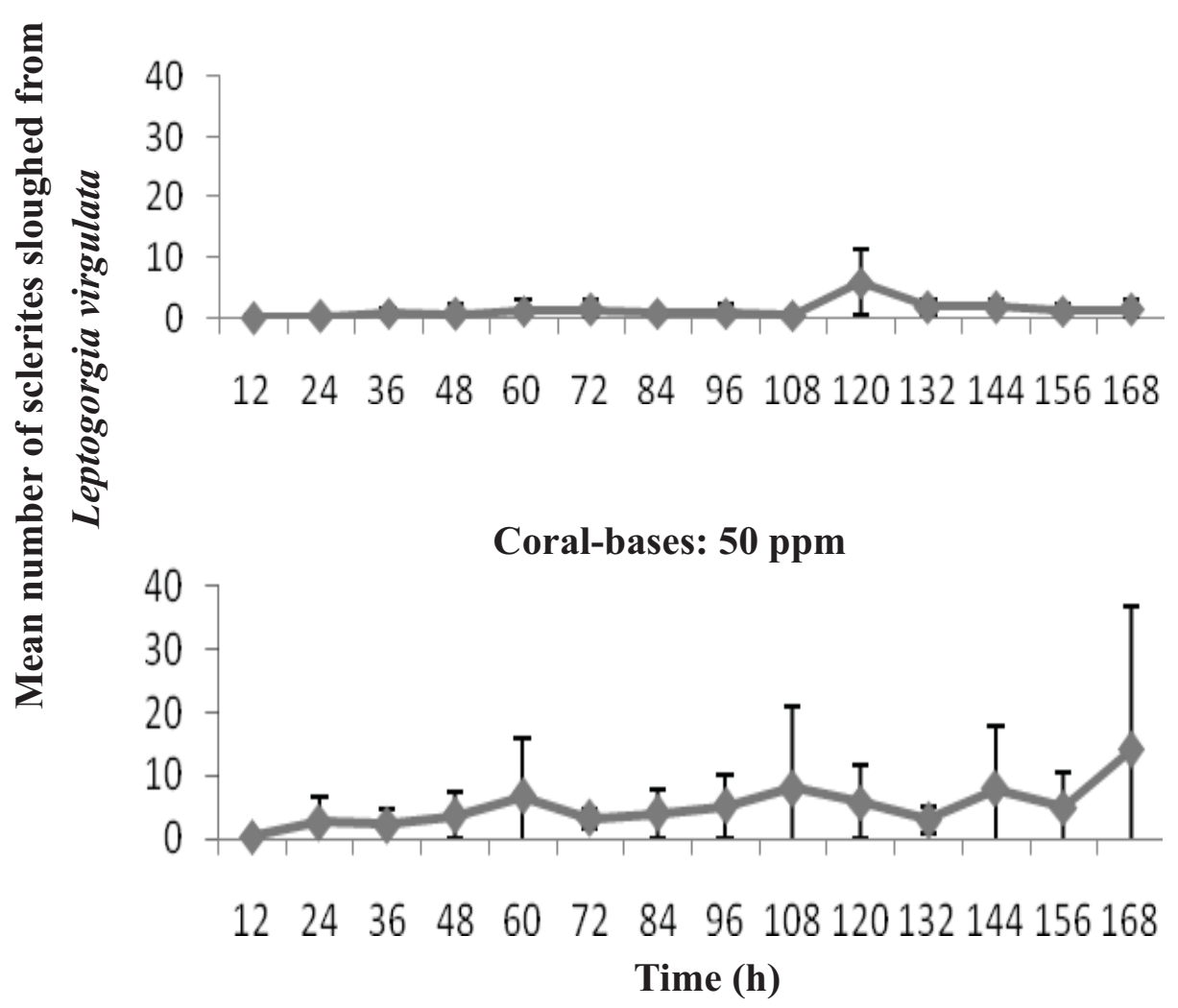

Figure 5. Average number of sclerites sloughed (i.e. lost/expelled) from the gorgonian coral Leptogorgia virgulata when exposed to gasoline treatment $50 \mathrm{ppm}$ over a time period of $168 \mathrm{~h}$ (7 days); sampling occurred every $12 \mathrm{~h}$. Error bars represent $95 \%$ confidence intervals 